\title{
The Role of Forensic Accounting in Limiting Tax Evasion in the Jordanian Public Industrial Shareholding Companies through the Perspective of Jordanian Auditors
}

\author{
Mohammad Enizan Al-Sharairi ${ }^{1}$ \\ ${ }^{1}$ Irbid National University, Jordan \\ Correspondence: Mohammad Enizan Al-Sharairi, Irbid National University, Irbid, Jordan.
}

Received: November 2, 2017

Accepted: December 29, 2017 Online Published: December 30, 2017

doi:10.5539/ijef.v10n1p233

URL: https://doi.org/10.5539/ijef.v10n1p233

\begin{abstract}
This study aims at identifying the role of forensic accounting in limiting tax evasion in the Jordanian public industrial shareholding companies as well as identifying the most modern methods followed by the Jordanian industrial companies to evade the payment of due taxes. The study also concentrated on clarifying the fields in which forensic accounting is applied and reasons for its appearance. The researcher chose a random sample of external auditors affiliated to the Jordanian association of certified public accountants (JACPA) who had audited the financial statements of the public shareholding industrial companies in Jordan. The study produced a number of important results and recommendations most significantly that there is no statistically significant role of the forensic accounting in limiting the acquisition method of accounting and the misuse of materiality as methods of tax evasion followed in the Jordanian industrial companies, and that there is a statistically significant role of the forensic accounting in limiting the use of accounting estimates and revenue recognition as methods of tax evasion followed byJordanian industrial companies. The researcher also recommends for the competent governmental authorities to activate the role of forensic accounting as a method to limit the cases of tax evasion.
\end{abstract}

Keywords: forensic accounting, tax evation, Jordanian auditors

\section{Introduction}

\subsection{Introduce the Problem}

Forensic accounting appeared as a modern domain which was recently applied through connecting it to judiciary. With the increasing size of the commercial and economic business in the world, several attempts appeared to develop accounting and accounting information to ensure its capacity to assimilate and confine the various methods of fraud, manipulation and adulteration. Here appeared the need of judiciary to accounting information and the prominence of the forensic accounting concept to present reports that guide the judgeship to issue sentences against the conflicting parties about financial matters. Thus we can say that forensic accounting is an integrated blend of both accounting and law to produce more profound and relevant investigations concerning different lawsuits.

Knowledge economy transferred all aspects of developed knowledge to different companies all over the world. This resulted in sharp competition among those companies to attract shareholders and stakeholders through presenting a beautified image of the company by using accounting and creative methods in profit management to maximize or reduce profits in an unrealistic manner (Scott, 2006).

Forensic accounting is based on studying financial statements and reports by forensic accountants who have complete knowledge about accounting aspects, judicial laws and connected procedures to reveal points of defect and manipulation and to decide those cases for all relevant parties. (Okoye \& Gbegi, 2013).

Therefore, this study will attempt to show the role and significance of forensic accounting in limiting tax evasion in the Jordanian public shareholding industrial companies.

Some companies purposively change their statements in an attempt of tax evation and illegal profit increase. However, this results in producing financial reports with different accounting numbers which mislead investors and make them take wrong decisions on one hand and create a state of tax evasion on the other hand. Needless to say that all the parties concerned with financial statements greatly concentrate on having correct and reliable 
financial statements and this is what brought focus on forensic accounting to limit the different manipulation methods like misusing materiality, using accounting estimates, acquisition accounting and revenue recognition practices and to uncover the points of defect and manipulation in addition to forcing businessmen to establish financial statements and reports free from any manipulation to be presented to the competent authorities and to terminate all the standing cases of all relevant parties (Huber, 2013).

With the increase in the tax values imposed on companies, this grave phenomenon - tax evasion - appeared threatening the state's economy and detainingthe achievement of its goals and economic and social policies. Hence, the study problem is embodied in the following questions: will there be a role for the forensic accounting in limiting tax evasion in the Jordanian industrial companies? From this main question stem the following questions:

1) Will there be a role of forensic accounting in limiting acquisition accounting as a method of tax evasion followed by the Jordanian industrial companies?

2) Will there be a role of forensic accounting in limiting the misuse of materiality as a method of tax evasion followed by the Jordanian industrial companies?

3) Will there be a role of forensic accounting in limiting the use of accounting estimates as a method of tax evasion followed by the Jordanian industrial companies?

4) Will there be a role of forensic accounting in limiting revenue recognition practices as a method of tax evasion followed by the Jordanian industrial companies?

\subsection{Explore Importance of the Problem}

The main targets of this study are:

1) Identifying the role of forensic accounting in limiting tax evasion in the Jordanian public shareholding industrial companies.

2) Shedding light on the forensic accounting concept, its goals, its fields and the reasons for its emergence as well as identifying the concept of tax evasion and its relationship with forensic accounting.

3) Showing the methods, styles and kinds of tax evasion followed by company managements.

The importance of this study comes from the significance of its subject matter which occupies a large size in moving the economic wheel in the state namely taxes and tax evasion with the income of those taxes to the public revenues of the state, as well as the damage suffered by the investors because of the companies' manipulation with their financial reports.

Therefore, it is necessary to fight such conduct which implies using fraud and manipulation methods. There should also be specialized professionals in the field of investigating tax evasion such as forensic accountants with the services they may present in exposing and limiting tax evasion.

\section{Describe Relevant Scholarship}

\subsection{Previous Studies}

The study of Ahmad (2013) under the title: "The role of forensic accounting in limiting financial corruption practices". The purpose of this study was to highlight the role of the forensic accountant in limiting the financial corruption practices by means of targeting a group of forensic accounting affiliates in charge in the accountability state authority, the administration of experts at the Ministry of Justice, accounting and auditing offices, the public taxes authority, capital market authority, tax appeals commission, Nile stock exchange, Egyptian universities, specialized training centers, Syndicate of commercial professions and the Egyptian accountants and auditors association and other representatives of the accounting and auditing profession. The researcher followed the descriptive analytical approach to answer the questions of the study which produced several results the most important of which are:

1) Forensic accounting is based on a set of integrated specialized skills in accounting and auditing and the excellence and skillfulness of investigations. It always looks beyond numbers.

2) Forensic accounting is used in many areas like cheat investigation, tax evasion and assessment of internal control and facilities in case of disputes.

3) The forensic accountant must have a set of skills and knowledge to be able to limit financial corruption. Of those skills are: Deep understanding to progressive accounting sciences, auditing and methods of investigation, sufficient familiarity with laws and legislations, criminal measures, litigation procedures and 
profound understanding to the fraudulent and misleading accounting methods.

The study presented several recommendations like the necessity of having a law that specifies the duties of the forensic accountant at courts and challenge committees at tax departments, developing the mission of the expert pursuant to the forensic accounting requirements, raising the competency of controlling and supervising commissions, fast deciding to the legal disputes, reducing the conflicts between the financier and the tax authority and the impact of all that on tax earnings through reconsidering the tax departments' procedures, assigning a forensic accountant to check the financial statements presented by financiers without being satisfied with the legal clause which obliges them to present those statements in specific dates.

(Diqabriel \& Ojb, 2013) "Objectivity and Independence: The dual roles of external auditors and forensic accountants".

This study aimed at clarifying the existed limited capabilities where we see the dual role of the external auditor by getting acquainted with the internal auditing and personal skills rules. It also aims at highlighting the reason for concentrating on the internal controls in addition to referring to the traditional auditing techniques. The published literature contributed in shedding light on the reason that calls for merging the external auditing responsibilities with those of the internal auditing, facilitating this step, suggesting simplifying methods and concentrating on its outcomes. The study also draws attention to the main features of the external auditor like objectivity and independence in order to limit the risks of role overlap considering that those features support the main role of the forensic accountant which is consultation and performing professional testimony in court. The researcher believes that researchers have to support the dual roles of the external auditor which give maximum priority to ethical values. This study also indicates that dual roles are relevant in some cases because of the constraints dictated by Sarbanes - Oxley act and other relevant enactments.

(Parbowo, 2013) "Better, Faster, Smarter Developing a blueprint for creating forensic accountants".

This study aimed at formulating the outlines of the main characteristics of the forensic accountant and framing a blueprint as a reference for teaching and training the forensic accountant. To achieve the objectives of the study, the researcher collected the required data referring to previous studies beside having interviews with a number of forensic accountants in Indonesia and U. S. A. The study revealed the presence of variance of the skills which should be available with the forensic accountant which distinguish them from other accountants and auditors. The study also pointed out a group of skills and capabilities the forensic accountant ought to possess like the ability of finding out the points of tax evasion, fraud and financial deceit and identifying the suspected and manipulatable areas and recommended the necessity to increase the awareness of those skills and to disseminate them among accountants and auditors.

(Huber, 2013) "Should the Forensic Accounting Profession be regulated?"

This study aimed at establishing international legislations or accounting laws that incorporate all aspects and dimensions of the companies' financial statements and reports and preventing or at least limiting any manipulation. As for the recommendations of the researcher, they stated that the government is the most binding entity to censorship and consciousness increase to recognize the importance of forensic accounting in maintaining the authenticity and accuracy of the financial statements of companies in addition to creating legislations and laws to preserve the rights of any party that could be harmed by any manipulation in those statements.

Al-shatnawi, Alhosban, Alzuabi (2014) "Factors that Help Ease the Financial Gap in the Sales Tax Report Submitted by the Taxpayers to Pay th e Tax: From the Point View of Sales Tax Auditors in Jordan".

This study aims to identify ways to narrow the gap between the financial report revealed the sales tax auditor which follows the Sales Tax Department, and to identify the nature of the financial gap between the report of the auditor and the nature of the tax procedures to make sure of the validity of the data relating to the sales tax. this study find results like the Commissioners and consultancy offices with the help of the tax charged to provide tax returns violates the law of the General Sales Tax, The presence of erroneous application of accounting principles generally accepted Almgiwlh when preparing the accounting books and records either by tax auditors or by the taxpayers who provide tax declaration for revolving the General Sales Tax. The recommended: The need to retain charge of the books and accounting records and assets by the rules laid down in the law of the General Sales Tax. The need to do seminars pilot taxpayers about the difficulty in applying the requirements of the law of the general sales tax at the accounting treatment of revenue and controlled by tax-exempt. 


\subsection{Theoretical Framework}

\subsubsection{The Concept of Forensic Accounting}

It was defined by the American Institute of certified public Accountants as: "Forensic accounting involves the application of specialized skills to collect, analyze and evaluate evidential matter and to interpret and communicate findings, whereby forensic accounting is performed in the form of attestation or consultation" (AICPA, 2005). Nevertheless, the researcher views forensic accounting as a homogeneous mixture that links accounting and auditing with judiciary through a legal point of view to present reports that contribute in eventually solving arguments and disputes.

\subsubsection{Forensic Accounting Objectives}

Forensic accounting attempts to realize a number of objectives from which are:

1) Providing financial and accounting reports for legal purposes acting as a dynamic bridge that connects the accounting system with the juridical system and providing analyzed accounting statements prepared for courtrooms to decide the lawsuits under dispute.

2) Identifying the illegal practices of companies and collecting important evidences in order to present a rich neutral opinion that helps in deciding lawsuits and disputes.

3) Looking into the claims of the relevant parties for the purpose of verifying them as the forensic accountant depends on the reason for their appointment, so their task could be checking the presence of fraud or concealing some economic damages.

4) Calculating the real and potential economic losses and damages and collecting financial evidence to support the legal claims to redeem those amounts, spotting the lost assets to be recollected and identifying the person responsible for the fraud and cheat operations. (Golden et al., 2007) (Al-Jalili, 2012, p. 41) (Cantroria, 2010, p. 3).

\subsubsection{Reasons for Forensic Accounting Appearance}

Forensic accounting started to receive attention upon the existence of financial corruption where the need to regain the trust of financial statements users became a must to maintain the foundations of economy. However, some other reasons gave necessity to forensic accounting more widely and inclusively such as:

1) The widespread of corruption and fraud in many companies and institutions like an epidemic that hits everything, hampers the development process, violates laws and rules and reveals the practices of using the authorities granted by different administrative entities.

2) The expectations gap related to auditors, their expected actions during auditing and what they actually produce. While the financial statements users expect the auditor to uncover cheat and corruption that may take place in different companies, we adversely find that the current auditing standards and the scientific and practical qualification of auditors do not enable them to realize this task, and this was an adequate cause for the emergence of forensic accounting which narrowed the expectations gap in auditing.

3) The traditional role of the auditor which lacks the ability of uncovering fraud even though such responsibility is held by them.

4) The need of jurisdiction and courts to experts capable to provide financial and accounting information for legal purposes to solve disputes. With the spread of corruption and the increase of fraud, problems aggravated, the conflict between disputing parties intensified, the lawsuits which touched upon new areas grew and the complication of legislations and pressure in the litigation context incremented which demonstrated the need of jurisdiction to financial experts and consultants to support it with their opinions and expertise by submitting detailed and simplified reports about the perpetrated financial violations. (Radi, 2011).

Thus, it can be said that forensic accounting is the offspring of the globalization of commerce, service exchange and E-commerce that opened new horizons in the mutual trade among many parties, and with the growing competition, resorting to cheat and fraud was one of the causes which misled investors and involved them in raw deals.

\subsubsection{Concept of Tax Evasion}

Tax evasion is defined as: The attempt of a taxpayer not to pay the due taxes totally or partly by following ways and methods that contradict the taxing system provisions, i.e have cheating and fraudulent nature: (Al-Khatib, 2000). 
It is also defined as: "An act that violates law where the taxpayer refrains from paying taxes or reduces the tax to a less value than that they have to abide to". (Mclaren, 2008).

\subsubsection{Manners of Tax Evasion}

Many methods are adopted by individuals and companies to evade tax payment. In its report of 2012, The United States Agency for International Development pointed out that most of the tax evasion cases pursued by the income and sales tax department in Jordan are related to the general sales tax and other cases of not presenting tax statements or increasing the expenses related to the works of companies and enterprises. The practical methods used in tax evasion can be summarized in the following:

First: Manners of income tax evasion of individuals and companies.

1) Non registration at the income tax authority where a number of people who have high income were found receiving fuel support allowance because they are not registered at the income tax department or at the social security corporation.

2) Not disclosing any information about the size of the taxpayer's activities, and this applies on some practitioners like doctors, engineers and lawyers where the basis of the taxable income calculation is determined by their unions.

3) Not delivering the tax deductions of the workers' income in some factories and companies.

4) Probationary Period: A method of fraud on the labour law by not paying the social security contributions as this period gives the employer the right to terminate the contract without giving reasons during this period. (The Jordanian economic council, 2014).

Second: Manners of customs duties evasion:

1) Manipulating the invoices that specify the value of imports by the taxpayer.

2) Changing the specifications of imported goods.

3) Importing in the names of other people by getting import cards and licenses.

4) Smuggling goods in different ways. (The Jordanian economic council, 2014).

Third: Manners of sales tax evasion:

1) Non - registration at the income and sales tax department as the sales tax law stipulates the registration limits of sales tax in by J.D (75000) for the commercial sector, J.D (50000) for the industrial sector and J.D (30000) for the service sector for the period of twelve successive months. Those limits gave the chance to a number of workers in the different economic sectors to claim that they did not reach at the registration limits.

2) Not delivering the sales tax deductions to the income and sales tax department

3) Manipulating the values of sale invoices.

4) Reducing the values of sale invoices in case of cash payment (The Jordanian economic and social council. 2014).

\subsubsection{Ways of Fighting Tax Evasion}

There are many possible methods and ways to fight tax evasion such as:

1) Developing the awareness and feelings of individuals that paying taxes is more ethical act than legal obligation.

2) Levying appropriate penalties and sanctions on the tax evading companies and establishments as a kind of deterrence.

3) Reformulating tax laws, blocking legal breaches and closing the hatch of legal evasion.

4) Implementing an equitable tax system that does not have low or severe raising pressure.

5) Stabilizing the tax system by lessening tax modification with no abundant changes in the employees.

6) Utilizing tax funds in a way useful to the society making the individuals feel the benefits of paying taxes (Ministry of Finance, 2014).

\subsubsection{Factors Leading to Tax Evasion}

1) The instability of the tax system and muchness of its amendments which made it hard to understand and 
encouraged its evasion.

2) The attempt of taxpayers to avoide the bureaucratic procedures of the departments authorized with collecting taxes.

3) The leniency in imposing sanctions on tax dodgers which encouraged them to continue the evasion process.

4) The weak control and competency of the investigation and collection authorities which facilitated tax evasion acts. (Annual report of the income and sales tax department the strategic plan, 2012-2014).

5) The taxpayers' sense of not receiving clear benefits against the taxes they pay.

6) Weakness of tax awareness and the feeling of unjustness in imposing taxes on different economic establishments.

7) The rise in living costs due to the general rise of prices (The Jordanian economic and social council, 2014).

\section{State Hypotheses and Their Correspondence to Research Design}

Main hypothesis: There is no statistically significant role of the forensic accounting in limiting tax evasion in the Jordanian industrial companies. From the main hypothesis stem a number of sub - hypotheses:

1) There is no statistically significant role at $(a=0.05)$ of the forensic accounting in limiting acquisition accounting as a method of tax evasion followed in the Jordanian industrial companies.

2) There is no statistically significant role at $(\mathrm{a}=0.05)$ of the forensic accounting in limiting the misuse of materiality as a method of tax evasion followed in the Jordanian industrial companies.

3) There is no statistically significant role at $(a=0.05)$ of the forensic accounting in limiting the use of estimates as a method of tax evasion followed in the Jordanian industrial companies.

4) There is no statistically significant role at $(a=0.05)$ of the forensic accounting in limiting revenue recognition practices as a method of tax evasion followed in the Jordanian industrial companies.

\section{Method}

The study model was established as shown in Figure 1. The model represents the variables which point out the role of forensic accounting in limiting tax evasion.

Independent variable: the influential factor on tax evasion

Dependent variable: tax evasion
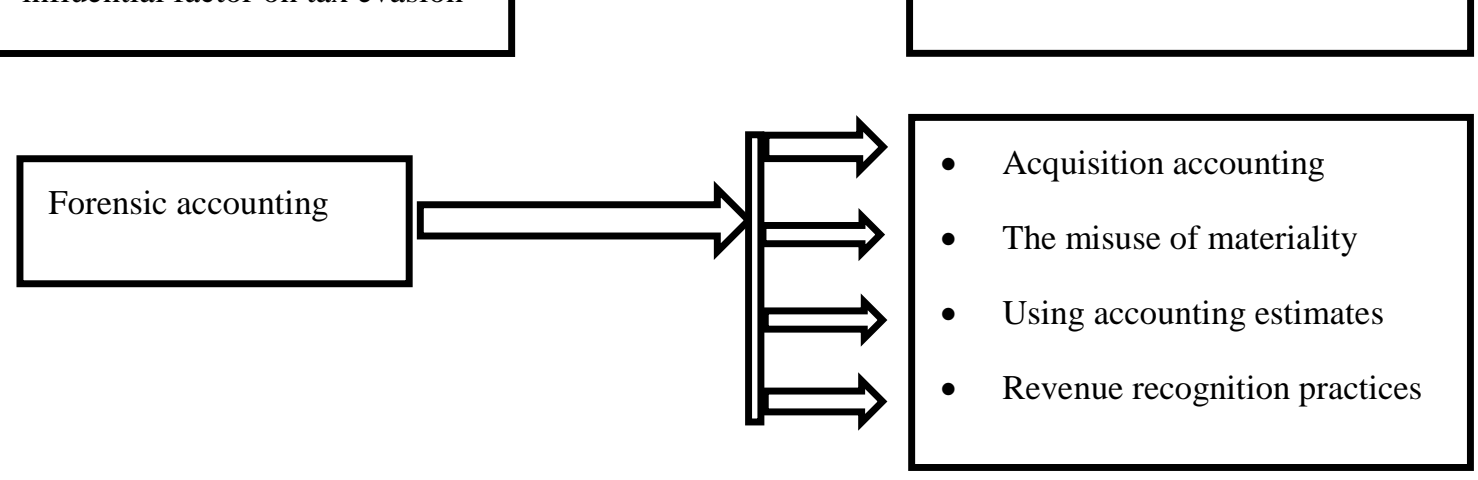

\subsection{Identify Subsections}

In order to achieve the expected objectives of this study, a questionnaire was prepared depending on the previous literature and studies which were conducted on the largest professional organizations concerned with tax evasion (See Appendix).

(60) questionnaires were distributed on external auditors registered at the Jordanian association of certified public accountants where (55) questionnaires at the rate of (92\%) of the total number of questionnaires were retrieved, and the quintet Likert scale was adopted to determine the significance level of each of the questionnaire items. As for the reliability of the study tool, the internal reliability of the tool's axes was calculated as well as the overall reliability by using Cronbach's Alpha reliability coefficient through (Test and Retest) whereby the reliability coefficient of the tools' axes ranged between $(0.69)$ and $(0.88)$ and the overall 
reliability coefficient of the tool was (0.80) which is an acceptable rate in this type of studies. See Table 1.

Table 1. Reliability coefficient of the tools

\begin{tabular}{lc}
\hline Variable & Cronbach's Alpha \\
\hline Acquisition accounting & 0.78 \\
The misuse of materiality & 0.88 \\
Using estimates & 0.83 \\
Revenue recognition practices & 0.69 \\
Overall reliability & 0.80 \\
\hline
\end{tabular}

\subsection{Participant (Subject) Characteristics}

It concentrates on a number of methods that can be followed to evade paying the tax partly or completely. They are a set of modern methods for evasion and are represented in acquisition accounting in its various types, the misuse of materiality and estimates and the mechanism of revenue recognition. Within the boundaries of the researcher's knowledge,this study is of the headmost studies which handled those accounting methods of tax evasion in Jordan.

\subsection{Sampling Procedures}

(60) external auditors were randomly chosen from the external auditors registered in the Jordanian association of certified accountants according to the statistics of 2017.

\subsubsection{Sample Size, Power, and Precision}

This study was restricted to a random sample of the study population the industrial public shareholding companies in Jordan located in Amman, Irbid and Zarqa.

\subsubsection{Measures and Covariates}

The researcher will rely on the descriptive and analytical approach in this study whereby the necessary data will be acquired from two basic sources:

1) The secondary sources represented in scientific books, previous studies and the researches published in the scientific periodicals and journals, statistics and websites which tackled the role of forensic accounting in limiting tax evasion.

2) The primary sources: Through designing a questionnaire that aims at measuring the likelihood of applying forensic accounting in limiting tax evasion in the Jordanian shareholding industrial establishments through the perspective of auditing offices and through analyzing data by means of using the statistical package of social sciences (SPSS) to test the validity of the hypotheses.

\subsection{Statistics and Data Analysis}

After applying the study tool in its final form and getting the required data, the researcher entered the data to the statistical program (SPSS) to perform the necessary tests which were represented in the following:

1) Calculating Cronbach's Alpha reliability coefficient of the study tool's axes to verify their reliability.

2) Frequencies, means, standard deviations and percentages of the study sample's members and its tool.

3) $\mathrm{T}$ - test.

\section{Results of the Main Study Hypotheses Test}

First hypothesis: There is no statistically significant role at the significance level Alpha (0.05) of forensic accounting in limiting acquisition accounting as one of the tax evasion methods followed by the Jordanian industrial companies.

Table 2. The arithmetic means, standard deviations and $\mathrm{T}$ - value of the study sample members responses to the issue of the role of forensic accounting in limiting acquisition accounting as one of the tax evasion methods followed by the Jordanian industrial companies

\begin{tabular}{cccccc}
\hline \multirow{2}{*}{$\begin{array}{c}\text { Acquisition } \\
\text { accounting }\end{array}$} & Arithmetic mean & Standard deviation & df & value & Sig \\
\hline
\end{tabular}


Viewing the previous table, we see that there is no statistically significant role at the significance level Alpha (0.05) of forensic accounting in limiting acquisition accounting as one of the tax evasion methods followed by the Jordanian industrial companies where the value of the calculated significance level was higher than the value of the significance level Alpha (0.05), and consequently the acceptance of the null hypothesis and the rejection of the alternative one.

Second hypothesis: There is no statistically significant role at the significance level Alpha (0.05) of forensic accounting in limiting materiality as one of the tax evasion methods followed by the Jordanian industrial companies.

Table 3. The arithmetic means, standard deviations and $\mathrm{T}$ - value of the study sample members responses to the issue of the role of forensic accounting in limiting the misuse of materiality as one of the tax evasion methods followed by the Jordanian industrial companies

\begin{tabular}{ccccccc}
\hline Materiality & Arithmetic mean & Standard deviation & df & T & value & Sig \\
\cline { 2 - 6 } & 51.87 & 2.97 & 54 & 1.05 & 0.08 \\
\hline
\end{tabular}

Viewing the previous table, we see that there is no statistically significant role at the significance level Alpha $(0.05)$ of forensic accounting in limiting the misuse of materiality as one of the tax evasion methods followed by the Jordanian industrial companies where the value of the calculated significance level was higher than the value of the significance level Alpha (0.05), and consequently the acceptance of the null hypothesis and the rejection of the alternative one.

Third hypothesis: There is no statistically significant role at the significance level Alpha (0.05) of forensic accounting in limiting the use of accounting estimates as one of the tax evasion methods followed by the Jordanian industrial companies.

Table 4. The arithmetic means, standard deviations and $\mathrm{T}$ - value of the study sample members responses to the issue of the role of forensic accounting in limiting the use of accounting estimates as one of the tax evasion methods followed by the Jordanian industrial companies

\begin{tabular}{ccccccc}
\hline \multirow{2}{*}{ Accounting estimates } & Arithmetic mean & Standard deviation & df & T & value & Sig \\
\cline { 2 - 6 } & 86.75 & 1.03 & 54 & 7.58 & 0.000 \\
\hline
\end{tabular}

Viewing the previous table, we see that there is statistically significant role at the significance level Alpha (0.05) of forensic accounting in limiting using accounting estimates as one of the tax evasion methods followed by the Jordanian industrial companies where the value of the calculated significance level was less than the value of the significance level Alpha (0.05), and consequently the acceptance of the alternative hypothesis and the rejection of the null one.

Fourth hypothesis: There is no statistically significant role at the significance level Alpha (0.05) of forensic accounting in limiting revenue recognition practices as one of the tax evasion methods followed by the Jordanian industrial companies.

Table 5. The arithmetic means, standard deviations and $\mathrm{T}$ - value of the study sample members responses to the issue of the role of forensic accounting in limiting revenue recognition practices as one of the tax evasion methods followed by the Jordanian industrial companies

\begin{tabular}{cccccc}
\hline Revenue recognition & Arithmetic mean & Standard deviation & df & T value & Sig \\
practices & 92.85 & 0.98 & 54 & 12.52 & 0.000 \\
\hline
\end{tabular}

Viewing the previous table, we see that there is statistically significant role at the significance level Alpha (0.05) of forensic accounting in limiting revenue recognition practices as one of the tax evasion methods followed by the Jordanian industrial companies where the value of the calculated significance level was less than the value of the significance level Alpha (0.05), and consequently the acceptance of the alternative hypothesis and the rejection of the null one. 


\section{Results}

1) The familiarity of the external auditors in Jordan with the importance of activating the role of forensic accounting to confine the devised tax evasion methods practiced by various industrial companies.

2) Forensic accounting is not the method to be used by the external auditor to detect tax evasion cases.

3) There are no governmental authorities specialized in forensic accounting which are in charge of monitoring industrial companies or any other companies.

4) Forensic accounting is one of the most successful methods in limiting the cases of tax evasion practiced by some industrial companies in Jordan.

\section{Recommendations}

1) Activating the role of forensic accounting as one of the methods of limiting the cases of tax evasion.

2) Holding training courses and workshops for external auditors to acquaint them with the importance of forensic accounting.

3) The researcher advises the Jordanian industrial companies to avoide tax evasion attempts and paytheir due taxes to help the Jordanian economy grow and flourish.

4) Conducting more field studies and researches to identify the most modern tax evasion methods followed by the Jordanian companies and to put preventive plans against those practices.

5) The researcher also recommends the necessity of founding a governmental authority specialized in forensic accounting and fully aware of accounting and jurisdiction.

\section{References}

Ahmad, K. M. A. (2013). The Role of Forensic Accounting in Limiting the Financial Corruption practices. First internation conference in accounting and auditing, Faculty of Commerce, BaniSweif university in collaboration with the Arab Universities Union, under the title: Activating the accounting and auditing mechanisms to fight financial and administrative corruption (7 - 8) April (2013).

AICPA. (2005). Forensic and Litigation Services Committee Developed the definition. Retrieved from https://www.aicpa.org/

Al-Jalili, A. M. (2012). Forensic Accounting and its Applicability in Iraq. Al-Rafidein Development Journal, 34(107).

Al-shatnawi, H., Alhosban, A., \& Alzuabi, N. (2014). Factors that Help Ease the Financial Gap in the Sales Tax Report Submitted by the Taxpayers to Pay th e Tax: From the Point View of Sales Tax Auditors in Jordan. International Journal of Economics and Finance, 6(6). https://doi.org/10.5539/ijef.v6n6p212

Golden, T. W., Skalak, S. L., \& Clayton, M. M. (2007). A Guide to Forensic Accounting Investigation. John Wiley and Sons, Inc.

Huber, W. (2013). Should the forensic accounting profession be regulated? Research in Accounting Regulation Journal, 25.

Huber, W. D. (2013). Forensic Accountants, Forensic Accounting Certifications, and Due Diligence. Journal of Forensic and Investigative Accounting, 5(1), 182-203.

Jordanian economic and social council. (2014). Tax evasion in Jordan (causes, methods, size). Amman Shmeisani, Jordan.

Mclaren, J. (2008). The Distinction between tax Avoidance and tax Evasion has become blurred in Australia: Why has it happened? Journal of the Australasian Tax Teachers Association, 3(2).

Ministry of Finance. (2012-2014). Income tax department, the strategic plan of the income and sales tax department, Amman, Jordan. Retrieved from http://www.mof.gov.jo/

Okoye, E. I., \&Gbegi, D. O. (2013). Forensic Accounting: A Tool for Fraud Detection and Prevention in the Public Sector (A Study of Selected Ministries in Kogi State). International Journal of Academic Research in Business and Social Sciences, 3(3).

Radi, M. S. (2001). Progressive Auditing Encyclopedia. University education house, Alexandria, Egypt.

Scott, F. (2006). Forensic Accounting Defined: From Forensic Accountants Financial Investigators, Les Nunn. University of Southern Indiana. Journal of Business and Economics Research, 4(2). 
The Annual report of the income and sales tax department strategic plan. (2012-2014).

\section{Appendix}

Dear brother / sister, ......

May peace and blessings of Allah be upon you.

With due appreciation and respect, I kindly ask for your cooperation to accomplish this study through filling in the attached questionnaire which comprises five axes about the subject of:

The Role of Forensic Accounting in Limiting Tax Evasion in the Jordanian Public Industrial Shareholding Companies through the Perspective of Jordanian Auditors.

Putting into consideration that all the information you provide will be treated in full confidentiality and will not be used except for the scientific research purposes. We promise to furnish you with a copy of the research results upon its termination.

Please accept our best regards and respect....

Researcher:

Dr. Mohammad Al-Sharai

Faculty of Administrative and Financial Sciences

Accounting Department

Irbid National University

First Axis: Demographic Data

\section{Academic qualification}

1. Diploma.............( )

2. Bachelor's Degree..( )

3. Higher Studies......( )

\section{Academic Major}

1. Accounting. $(\quad)$

2. Other........( )

\section{Gender}

1. Male.....( )

2. Female..( )

\section{Years of Experience}

1. Less than 5 years....( )

2. From 5 to $10 \ldots . . . . .($ )

3. From 11 to $16 \ldots . . . . .($ )

4. From 17 to $20 \ldots \ldots . .(\quad)$

\begin{tabular}{|l|l|l|l|l|l|l|}
\hline A.2 & Acquisition accounting: & Strongly agree & agree & neutral & Disagree & Strongly disagree \\
\hline 1 & $\begin{array}{l}\text { Acquisition accounting methods can be used by } \\
\text { industrial companies to evade paying taxes }\end{array}$ & & & & \\
\hline 2 & $\begin{array}{l}\text { The Jordanian industrial companies resort to acquisition } \\
\text { accounting as a tax evasion method }\end{array}$ & & & & & \\
\hline 3 & $\begin{array}{l}\text { Forensic accounting helps in limiting the tax evasion } \\
\text { based on acquisition accounting }\end{array}$ & & & & & \\
\hline
\end{tabular}




\begin{tabular}{|c|c|c|c|c|c|c|}
\hline A. 3 & Misusing materiality & Strongly agree & agree & neutral & Disagree & Strongly disagree \\
\hline 4 & $\begin{array}{l}\text { Misusing materiality by the Jordanian industrial } \\
\text { companies helps in tax evasion }\end{array}$ & & & & & \\
\hline 5 & $\begin{array}{l}\text { The Jordanian industrial companies resort to misusing } \\
\text { materiality as a tax evasion method }\end{array}$ & & & & & \\
\hline 6 & $\begin{array}{l}\text { Forensic accounting helps in limiting the tax evasion } \\
\text { based on misusing materiality }\end{array}$ & & & & & \\
\hline A. 4 & Using accounting estimates & Strongly agree & agree & neutral & Disagree & Strongly disagree \\
\hline 7 & $\begin{array}{l}\text { Using accounting estimates by Jordanian industrial } \\
\text { companies helps in tax evasion. }\end{array}$ & & & & & \\
\hline 8 & $\begin{array}{l}\text { The Jordanian industrial companies resort to using } \\
\text { accounting estimates as a tax evasion method }\end{array}$ & & & & & \\
\hline 9 & $\begin{array}{l}\text { Forensic accounting helps in limiting the tax evasion } \\
\text { based on using accounting estimates }\end{array}$ & & & & & \\
\hline A. 5 & Revenue recognition practices & Strongly agree & agree & neutral & Disagree & Strongly disagree \\
\hline 10 & $\begin{array}{l}\text { Misusing revenue recognition practices by the Jordanian } \\
\text { industrial companies helps in tax evasion }\end{array}$ & & & & & \\
\hline 11 & $\begin{array}{l}\text { The Jordanian industrial companies resort to using } \\
\text { revenue recognition practices as a tax evasion method }\end{array}$ & & & & & \\
\hline 12 & $\begin{array}{l}\text { Forensic accounting helps in limiting the tax evasion } \\
\text { based on misusing revenue recognition practices }\end{array}$ & & & & & \\
\hline
\end{tabular}

\section{Copyrights}

Copyright for this article is retained by the author(s), with first publication rights granted to the journal.

This is an open-access article distributed under the terms and conditions of the Creative Commons Attribution license (http://creativecommons.org/licenses/by/4.0/). 